\title{
Contribution of Official Development Assistance to Poverty Alleviation In The Ecowas
}

\author{
N'dri Kan David \\ Economic Department / University Felix Houphouet Boigny, Ivory Coast
}

\begin{abstract}
This thesis studies the effect of Official Development Assistance (ODA) on Poverty in the Economic Community of West African States (ECOWAS). The transmission channel extends from ODA to Poverty alleviation through economic growth. Using panel data from 1980 to 2014 and a four-equation simultaneous model, the results show that ODA contributes to reduce poverty, measured by the infant mortality rate. However, its effect on economic growth was found to be harmful. Therefore, it can be concluded that ODA is pro-poor, but not growth enhancing in West African countries. A policy implication of this study is that ECOWAS member countries should adopt strategies and policies in order to use the foreign aid to achieve both objectives, which consist of promoting economic growth and reducing poverty.
\end{abstract}

Keywords: Official Development Assistance, Poverty, Panel VAR, Simultaneous equation

\section{Introduction}

Though the effectiveness of foreign aid has been widely discussed over the years, there is no consensus among researchers. On the one hand, there are those such as Boone (1996) who finds that ODA does not increase investment and growth; while on the other hand, Hansen and Tarp (2000) and Dalgaard (2004), argue that Official Development Assistance (ODA) has a positive impact on growth, but with diminishing returns as the volume of aid increases. Furthermore, according to Burnside and Dollar (2000), there is an intermediate position whereby foreign aid has a positive and significant impact on growth only in developing countries with good fiscal, monetary and trade policies. However, more recently, the focus on aid effectiveness has moved from economic growth to poverty reduction which represents one of the major Sustainable Development Goals (SDGs). On that point, Collier and Dollar (2002) find that the actual allocation of aid is radically different from poverty-efficient allocation and has suggested that with a poverty-efficient allocation, the productivity of aid would nearly double. Also, according to Mosley and al (2004), a key determinant of the aid's poverty leverage is to conduct a 'pro-poor public expenditure' policy, together with measures against inequality and corruption.

Likewise, for the UNDP (2005), International aid remains one of the most powerful weapons in the war against poverty. However, after several decades of aid inflows, persistent differences between the stated objectives and their implementation remain disconcerting in some countries. Particularly in SubSaharan Africa (SSA), the impact of ODA on poverty reduction seems slightly significant.

Indeed, during the 2002-2009 period, Africa received the largest part of ODA from donor countries: out of approximately US $\$ 483$ billion, nearly $35 \%$ were attributed to African countries (OECD, 2010). Yet poverty rates were not significantly improved. On average, 45 to $50 \%$ of the African population still live below the international poverty threshold of US $\$ 1.25$ a day (World Bank, 2013a). The poverty gap, often considered as representing the depth of poverty and defined as the mean distance separating the population from the poverty line with the non-poor being given a distance of zero, is the highest in Africa (World Bank, 2013a). Furthermore, access to education and social health services still remain great challenges in West African States. According to the UN inter agency Group for child mortality, Sub-Saharan Africa has the highest under-five mortality rate. In 2015, 1 in 12 children in SubSaharan Africa died before 5 years old; which is more than 12 times higher than the 1 in 147 rate in high income countries.

The area of this study is the ECOWAS (Economic Community of West African States). According to the latest survey available for each country, also based on national poverty lines, the poor represented less than one third of the population in Benin, Ghana, and Togo. There are more than one third of the population in Cape Verde and Cote d'Ivoire; and, about one and a half of the population was living below the national poverty line in Burkina Faso, Gambia, Guinea, Nigeria and Senegal. Nearly two thirds of the population was poor in Guinea Bissau and Niger and, more than 2/3 of the population was poor in Mali and Sierra Leone (ECOWAS, 2007).

Although this region is considered to be the poorest in Africa, it has not yet been an exclusive subject of study regarding aid effectiveness. Most studies have included these countries in their sample, 
though there is heterogeneity among different regions. This thesis intends, therefore, to fill the existing lack. It aims at providing answers to the following questions:

Does ODA have an impact on poverty in West African countries? If yes, what is the real contribution of Official Development Assistance to poverty reduction in West African Countries? Through which channels does ODA affect the living conditions of the population?

This paper will contribute to the ongoing debate about aid effectiveness. Recently, voices were raised, in particular Moyo (2009), claiming that Aid is not working in Africa and that it should be replaced by Trade. Therefore, in this study, the veracity of such a claim will be assessed by scientific arguments. Focus is on West African Countries in order to reduce the heterogeneity that is inherent to cross-country analysis.

The study assesses the impact of ODA on poverty reduction within the ECOWAS. More specifically, it focuses on describing the flow of ODA by analyzing its evolution within the countries involved, assessing the impact of ODA through a quantitative analysis involving a Simultaneous equation model and examining the transmission mechanisms between poverty, economic growth and ODA.

The remainder is organized as follows: Chapter 2 presents an overview of the ODA repartition in the ECOWAS and the recent literature on the impact of Official Development Assistance. Chapter 3 introduces the empirical methodology, in particular the model and data. The results are presented in Chapter 4, and Chapter 5 provides a conclusion.

\section{Overview of ODA and Human Development in the ECOWAS 2.1. Official Development Assistance (ODA) in the ECOWAS}

Financial assistance to developing countries for socioeconomic development has been carried out by several organizations, governments, as well as international organizations, non-governmental organizations (NGOs) and private companies for a long time.

\subsubsection{ODA distribution according to regions}

According to the OECD (2014), the Sub-Saharan African region received the largest part of ODA in the world (40\%), followed by South and Central Asian countries (20.7\%). During the past three decades, it is estimated that the West African countries received regularly a quarter of the aid volume in direction of the Sub-Saharan countries. It was of $26 \%$ from 1980 to 1990, 25\% from 1991 to 2000 and $28 \%$ from 2001 to 2015 (OECD, 2016).

Furthermore, the majority of aid towards developing countries is composed of bilateral development projects, programs and technical cooperation. Multilateral aid represents the second largest source of aid, followed by humanitarian aid and debt relief. Looking at the graph below, one can observe a peak in year 2005 in the level of debt relief. This is explained by the important amount of debt cancellation for Nigeria and Iraq. Indeed, in 2005, in addition to the HIPC (Heavily Indebted Poor Countries) initiative, the Multilateral Debt Relief Initiative (MDRI) was initiated in order to accelerate progress toward the United Nations Millennium Development Goals (MDGs). The MDRI allows for 100 percent relief on eligible debts by three multilateral institutions; namely the IMF, the World Bank, and the African Development Fund (AfDF), for countries completing the HIPC Initiative process.

On the other hand, from 2005 to 2014, data on the distribution of bilateral ODA commitments reveal that donors' countries were willing to fund actions relating to debt cancelling and to improve social infrastructures in the ECOWAS. In those countries, likewise in most of Sub-Saharan countries, one important feature is the high level of dependence regarding international aid. Using data from 2004 to 2013, one can observe that countries in West Africa have been for a long time, dependent on ODA for government expenses. In some countries, such as Liberia, Niger and Burkina Faso, the ratio of aid dependence is beyond a hundred percent. This massive influx of aid reveals the lack of capital faced by these countries; furthermore, it may be a sign of deficiencies in the fiscal system. In addition to that, one can observe that on average, more than $20 \%$ of capital formation in West African countries is attributed to foreign aid. In Liberia and Guinea Bissau, this ratio is estimated at more than $100 \%$. Therefore, on the basis of the above, these countries should have experienced a better level of development.

\subsubsection{Human Development in the ECOWAS}

Despite progress made since 2000 in terms of economic growth, human development level in Africa still remains low. It is much lower than the world average. For the specific ECOWAS region, table 3 shows the level of human development in 2015 as calculated by the UNDP. Thirteen (13) countries of the fifteen (15) that compose the ECOWAS are classified as Low Human Development countries. Only Cabo Verde and Ghana have a medium human development index. 
Table 1: Classification of ECOWAS countries according to the Human Development Index in 2015

\begin{tabular}{|l|c|c|c|c|c|}
\hline & & HDI & $\begin{array}{c}\text { Life } \\
\text { expect } \\
\text { ancy at } \\
\text { birth }\end{array}$ & $\begin{array}{l}\text { Expected } \\
\text { years of } \\
\text { schooling }\end{array}$ & $\begin{array}{c}\text { Mean years of } \\
\text { schooling }\end{array}$ \\
\hline Cabo Verde & Medium HD & 0.646 & 73.3 & 13.5 & 4.7 \\
\hline Ghana & Medium HD & 0.579 & 61.4 & 11.5 & 7.0 \\
\hline Nigeria & Low HD & 0.514 & 52.8 & 9.0 & 5.9 \\
\hline Togo & Low HD & 0.484 & 59.7 & 12.2 & 4.5 \\
\hline Benin & Low HD & 0.480 & 59.6 & 11.1 & 3.3 \\
\hline Senegal & Low HD & 0.466 & 66.5 & 7.9 & 2.5 \\
\hline Cote d'Ivoire & Low HD & 0.462 & 51.5 & 8.9 & 4.3 \\
\hline Gambia & Low HD & 0.441 & 60.2 & 8.8 & 2.8 \\
\hline Liberia & Low HD & 0.430 & 60.9 & 9.5 & 4.1 \\
\hline Guinea-Bissau & Low HD & 0.420 & 55.2 & 9.0 & 2.8 \\
\hline Mali & Low HD & 0.419 & 58.0 & 8.4 & 2.0 \\
\hline Sierra Leone & Low HD & 0.413 & 50.9 & 8.6 & 3.1 \\
\hline Guinea & Low HD & 0.411 & 58.8 & 8.7 & 2.4 \\
\hline Burkina Faso & Low HD & 0.402 & 58.7 & 7.8 & 1.4 \\
\hline Niger & Low HD & 0.348 & 61.4 & 5.4 & 1.5 \\
\hline
\end{tabular}

Source: UNDP (2015)

In the sub-Saharan Africa, for example, the average level of human development in 1990 was 0.40 , compared to the world average of 0.60 . This level rose slightly to 0.50 in 2013 , but still remained $28 \%$ lower than the world average of 0.70 (UNDP, 2014).

A comparison of the infant mortality rate between countries in West and East Africa shows that although the trend is declining, however the level is higher in West Africa compared to the Eastern part of the continent; and to the world in general. The following figures 2 and 3 illustrate the relationship between ODA, infant mortality rate and the GDP growth rate. There seems to be a negative relationship between the infant mortality rate and international aid; however, this relationship is inelastic with regard to the link between aid and economic growth.

\section{The Relationship Between ODA, Economic Growth And Poverty: A Literature Survey} 3.1. Theoretical foundation and empirical evidences

The literature on aid effectiveness is abundant. Though for a long time, researchers have focused their attention on the impact of aid on economic growth; nowadays, interest has been given to the capacity of aid to reduce poverty and promote welfare.

Guillaumont (2009) identifies three main macroeconomic channels of aid effectiveness for poverty reduction. The first channel is from aid to growth, then from growth to poverty reduction. The second channel involves the impact of aid on the volume and composition of mainly social public expenditures, particularly on education and health, and the impact of these expenditures on corresponding poverty indicators. Finally, international aid can affect poverty levels through its stabilizing effect on economic growth. By making growth less volatile, aid both accelerates growth and makes it more propoor.

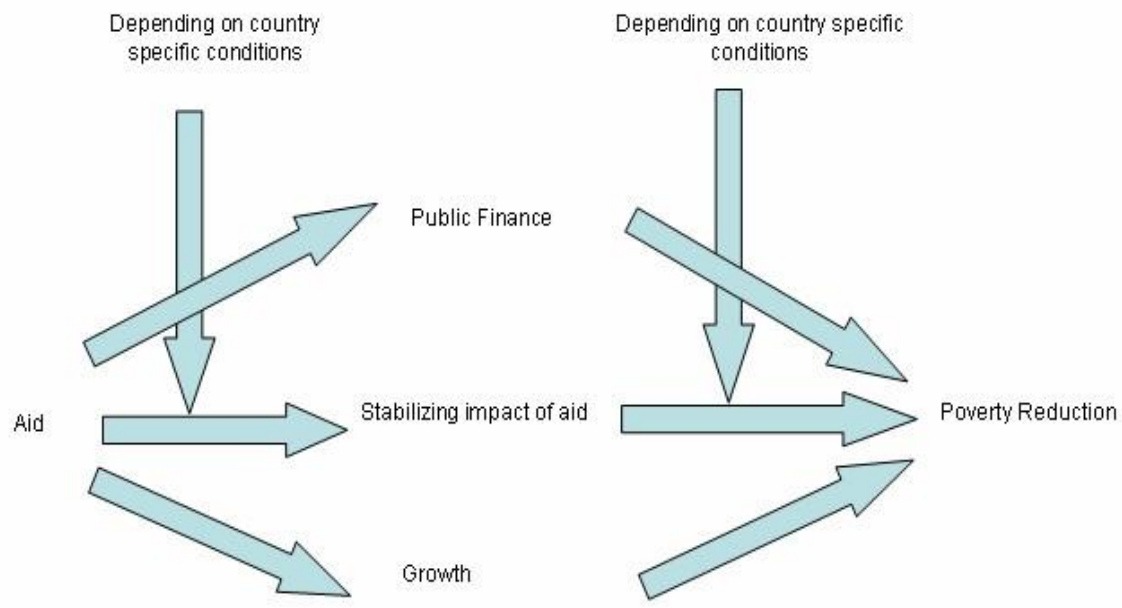

Source: P. Guillaumont (2011) 
Regarding the effect of aid on economic growth, one can refer to the studies of Burnside and Dollar (1997, 2000) and Collier and Dollar (2001, 2002).

Burnside and Dollar $(1997,2000)$ developed a model in which they include an interactive term. They make effectiveness depends on an indicator of macroeconomic policy, an average of indicators of openness, of fiscal balance and of monetary stability. Burnside and Dollar find that aid has a positive impact on growth only in the presence of good policies.

Collier and Dollar $(2001,2002)$ assess the effect of foreign aid on poverty. They derive a poverty-efficient allocation of aid and compare it with actual aid allocations. They assume that the positive effect of aid on growth depends on the quality of the economic policy. Then, they designed a linear program which enables an optimal aid allocation between the various countries to be calculated on the basis of the current level of total aid. This allocation is intended to equalize the marginal contribution of aid to reducing the number of poor per country, by taking into account the decreasing marginal impact of aid on growth, the initial incidence of poverty in each country, and the quality of their current economic policy.

However, the policy indicator used in these studies has been criticized by Amprou et al. (2007). They argue that using another index results in different assessment of selectivity. Easterly and al (2004) find also that by extending the period and the sample; and by using the same methodology as Burnside $(1997,2007)$, results are quite different.

In addition, Guillaumont and Chauvet (2001) working with longer periods (twelve years) find that the coefficient for the interactive variable between aid and policy is not significant.

Apart from the policy indicator suggested by Burnside (1997), others factors can influence the effect of aid on growth. Gomanee et al. (2005) in their analysis related only to Sub-Saharan Africa, find that in this region, the impact of aid on growth is channeled by investment.

Guillaumont and Chauvet (2001) reveal that economic vulnerability is a major factor conditioning aid effectiveness. In addition, they identify the political instability and absorptive capacity as factors influencing the relationship between aid and economic growth.

Recently, studies concluded on the positive effect of aid on economic growth using new estimation methods. CarlJohan Dalgaard et al(2004), using an endogenous growth model, demonstrates that cross-country data, are fully consistent with the positive evidence on aid effectiveness that emerge from recent panel-based regressions. Their empirical analysis suggests that aid is generally effective, even in bad environments. However, the degree to which aid enhances growth depends on climate-related circumstances. Askarov (2015) uses instrumental variables techniques to show that aid has a positive impact on economic growth in transitional economies. Aid effectiveness is not conditional on good policy and there is little evidence of non-linear growth effects arising from aid.

Eskander Alvi (2008) assesses the importance of policy and aid in generating growth when the aid, policy, and growth relationship is nonlinear. He finds that policy is an important determinant of growth, and that aid is growth enhancing in a good policy environment, as well as some evidence of diminishing returns to aid. The intuition of most researchers is that if foreign aid has a positive impact on growth and if growth reduces poverty, such aid should contribute to poverty reduction. Therefore, the impact of aid on poverty depends also on the income elasticity of poverty; that is how poverty reacts to a change in income level. Regarding the effect of aid on poverty, though few studies have tried to directly test the causal relationship, one can still refer to Collier and Dollar (2000). They assume that the income elasticity of poverty is uniform among countries; thus, they are able to find the optimal level of aid allocation that would reduce the number of poor in the world.

Collier (2002) examining the effectiveness of aid from the point of view of poverty reduction, uses infant mortality as an indicator of poverty for their regression analysis because of the paucity of poverty data. They conclude that the impact of aid on poverty depends on its impact on per capita income growth. For them, aid affects economic growth, which then contributes to poverty reduction.

Likewise, Kalwij and Verschoor (2002) identify the percentage reduction in poverty due to a onepercent increase in income which represents the growth elasticity of poverty. They find that aid can contribute to pro-poor growth by favoring countries with both good economic policies and good social policies, and by encouraging recipient governments to spend more on pro-poor sectors.

From another point of view, researchers considered that aid can benefit the poor without necessarily having any impact on monetary or income poverty, since aid can finance expenditures that improve the welfare of the poor, such as universal access to primary education and health care (Guillaumont, 2009). Therefore, some empirical analyses of the impact of aid on poverty refer to nonmonetary indicators of welfare, such as education and health status indicators. For instance, Mosley et al. (2002) have adopted a different approach; instead of a single equation relating aid to poverty, they use a generated regressor approach in order to take into account the endogeneity problem. 
Gomanee et al. (2003) test the hypothesis that aid can improve the welfare of the poor. They use cross-country regressions and unlike Collier and Dollar (2000), they concluded that aid can help to alleviate poverty independently of any effects via growth of reducing poverty. The transmission channel proposed is that aid finances pro-poor public expenditures, either directly or indirectly, and these expenditures increase welfare, which benefits the poor.

Morrissey et al (2004), using cross country data, investigate the effectiveness of aid in improving aggregate human welfare, as measured by the Human Development Index and the Infant Mortality. Their work adopts a simple specification, and addresses only the effect on welfare via pro-public expenditures; they find that aid reduces poverty by improving the HDI in recipients' countries.

Gomanee et al. (2005) estimate the direct effect of aid on welfare or poverty for a sample of 104 countries and find a positive direct impact on the quality of life, measured by Human Development Index (HDI), and infant mortality, but no impact of public social spending, although they found that aid tends to increase pro-poor expenditures for lowincome countries.

Moreover, Asra et al (2005) explore the causal link between macroeconomic policy and aid effectiveness in reducing poverty. They show that aid contributes to reducing poverty. In estimating their model, they directly include aid into a poverty equation with a set of control variables involving policy variables, governance variables and region dummies. In order to address the endogeneity coming from the reverse causality that can exist between aid and poverty level in a country, they include initial conditions as explanatories variables. These initial conditions are the logarithm of per capita GDP, logarithm of the population, infant mortality rate and the life expectancy in the beginning year. Finally, they include the Gini coefficient in the beginning year.

Sanjay G. Reddy and Camelia Minoiu (2006) disentangle the effects of two components of aid: a developmental, growth-enhancing component, and a geopolitical, possibly growth-depressing component. Their results indicate that aid of the right kind promotes long-run growth. The effect of developmental aid is significant, large, and withstands a battery of robustness checks including alternative proxies for developmental aid, specifications and treatments of outliers. Furthermore, they find no evidence that there are diminishing returns to aid and that aid is only effective in "good" policy environments.

Using the Generalized Method of Moments, Michaleowa and Weber (2007) show that there is no effect of aid on education. As for outcomes, they use primary completion rates and gross enrolment rates for secondary and tertiary levels. Wolf (2007) using a simultaneous equation model, finds that, overall, the share of Official Development Assistance (ODA) provided for education and health seems to have a positive impact on outcomes in these sectors, whereas total aid seems to be negatively associated. They use different outcomes such as education, health, water and sanitation. Regarding health, Mishra and Newhouse (2007) find a statistically significant, but small effect that doubling per capita health aid was associated with a 2 percent reduction in the infant mortality rate for 118 countries between 1973 and 2004. Arnt and al. (2011) find that according to the LIML point estimates, on average a sustained inflow of 25 USD aid per capita is expected to increase the rate of economic growth by around half a percentage point, reduce poverty by around 6.5 percentage points, raise investment by around 1.5 percentage points in GDP, augment average schooling by 0.4 years, boost life expectancy by 1.3 years and reduce infant mortality by 7 in every 1000 births. These effects refer to the expected change in the period averages of the outcome variables. This paper is in line with previous studies since it intends to assess the effect of aid on poverty.

\subsection{Model Specification}

\section{Methodology}

This study aims at assessing quantitatively the impact of aid on poverty reduction in West African countries. Adamu (2013) investigates the effect of Official Development Assistance on economic growth by focusing on the ECOWAS and using simultaneous equations with panel data. In this study, we intend to go further by analyzing the effect of ODA on poverty in the ECOWAS, through the capital accumulation and economic growth channel as identified by Guillaumont (2009). A simultaneous equations model is used in order to identify and measure both direct and indirect effects of aid. The model draws upon previous studies and is composed of four (4) equations:

\subsubsection{Poverty equation}

To explain poverty, the role of initial conditions, policies, and institutions have been emphasized by Dollar and Kraay (2002) and Hasan et al. (2003). As initial conditions, these authors included in the equation "poverty in the beginning year"; "log of per capita GDP in the beginning year"; "log of population in the beginning year";", infant mortality rate in the beginning year"; "life expectancy in the beginning year"; and "the Gini coefficient in the beginning year." Political determinants included are 
"share of arm import in total import" and "France zone". Dollar et al. also added some policy and governance variables and regions dummies.

The poverty equation is built on this literature. As poverty indicators are scarce, some human welfare indicators; namely, Human Development Index (HDI) and Infant mortality are used. These indicators have also been used by Burnside and Dollar (1998) and Mosley et al. (2002).

Povi $_{i, t}=\mathrm{a}_{0}+\mathrm{a}_{1}$ Initialcond $_{i, t}+\mathrm{a}_{2}$ ODA $_{i, t}+\mathrm{a}_{3} G D P_{i, t}+\mathrm{a}_{4}$ Pop $_{i, t}+\mathrm{a}_{5}$ Gov $_{i, t}+\mu_{i, t}$

\subsubsection{Economic growth equation}

The growth equation is based upon the Solow growth theory. According to the neoclassical growth theory, economic growth depends positively on human capital, physical capital (proxied by investment), exports, FDI, and foreign aid flows. It, however, depends inversely on interest rate (Adamu, 2013). Thereafter, researchers have included in this basic model, policy variables such as trade, fiscal policy and monetary policy. In this model, foreign aid is included and is expected to affect economic growth through capital accumulation.

$$
\begin{aligned}
& G D P_{i, t}=\mathrm{b}_{0}+\mathrm{b}_{1} O D A_{i, t}+\mathrm{b}_{2} \text { FDI }_{i, t}+\mathrm{b}_{3} \text { Invest }_{i, t}+\mathrm{b}_{4} \text { HumCap }_{i, t}+\mathrm{b}_{5} \text { Trade }_{i, t}+\mathrm{b}_{6} \text { Rint }_{i, t}+\mathrm{b}_{7} \text { Sav }_{i, t} \\
& +\mathrm{e}_{i, t}
\end{aligned}
$$

\subsubsection{Investment equation}

In their analysis related to Sub-Saharan Africa, Gomanee et al. (2005) find that in this region, the impact of aid on growth is channeled by investment. According to this finding, an investment equation is added in the model. This equation relies upon Adamu (2013) who specified the gross domestic investment as a function of gross total domestic savings, foreign aid, rate of interest, FDI and other variables such as exchange rate, inflation rate, a country dummy variable and a political dummy variable. The equation is as follows:

\subsubsection{Aid equation}

$$
\text { Invest }_{i, t}=\mathrm{C}_{0}+\mathrm{C}_{1} O D A_{i, t}+\mathrm{C}_{2} \operatorname{Sav}_{i, t}+\mathrm{C}_{3} \operatorname{Rint}_{i, t}+\mathrm{C}_{4} F D I_{i, t}+\mathrm{h}_{i, t}
$$

This equation is specified following Asra et al (2005) and Alessandro D. (2013). Aid is explained by the level of poverty, population growth rate, GDP growth rate and a governance indicator.

$$
O D A_{i, t}=\mathrm{d}_{0}+\mathrm{d}_{1} P_{o v} v_{i, t}+\mathrm{d}_{2} P_{o p}, t+\mathrm{d}_{3} G D P_{i, t}+\mathrm{d}_{4} G_{o v} v_{i, t}+\mathrm{g}_{i, t}
$$

\subsection{Data description}

The data are mainly from the Word Development Indicators (WDI, 2015) and the sample period is from 1980 to 2014. As this study intends to analyze the impact of ODA on poverty in West African countries, a set of dependent variables are selected. Rather than focusing on per capita income, as is common in the existing literature, the effect of foreign aid on a range of human development indicators is analyzed.

Two dependent variables were selected according to their availability; namely, infant mortality and the Human Development Index (HDI). Infant mortality is a health indicator used by organizations such as the OECD to measure poverty (OECD 2004, 2005, 2008). The HDI is a measure of average achievement in key dimensions of human development: a long and healthy life, being knowledgeable and have a decent standard of living (UNDP, 2014). It is the geometric mean of normalized indices for each of the three dimensions.

In the poverty equation, in addition to ODA per capita, others independent variables are the initial conditions variables which are the infant mortality at the beginning of the period, per capita GDP in the beginning year. Two (2) governance indicators are included; the first is the average of political right and civil liberties indicators from Freedom House country rating dataset, the second is an indicator constructed from the six governance indicatorsby using the principal component analysis. The GDP per capita is included to capture the effect of income level on poverty.

The ODA variable is expressed on a per capita basis, rather than as a percentage of GDP, as it is done in others studies. Indeed, the impact of aid on poverty should be assessed by the average amount allocated per poor (Arndt et al, 2010); since we do not have such variable, we use ODA per capita.

As far as the growth equation is concerned, aid per capita and its lag are included to capture the impact on economic growth. The introduction of a lagged aid is justified by the fact that the impact of aid is assumed to be perceptible after a certain time period. Others control variables are the per capita GDP in the beginning year; this variable is used to test for the convergence effect; the Gross Fixed Capital Formation as a proxy of investment, Foreign Direct Investment (FDI as a share of GDP), Trade (the sum 
of export and import of goods and services as a share of GDP) as an indicator of the trade between each country and the rest of the world, the amount of saving and a human capital index. Regarding the investment equation, in addition to the aid variables, the control variables are the savings, the real interest rate, and the FDI. In the aid equation, the initial level of GDP per capita and infant mortality is included as a measure of the initial poverty level in recipient countries. The population growth rate, the GDP per capita and the governance indicators are also included.

\subsection{Estimation procedures}

To account for the endogeneity, we estimate first a panel data vector autoregressive (VAR) model and a simultaneous equation model with panel data. The Panel VAR regression involves the four endogenous: infant mortality, GDP per capita and investment, ODA.

The use of a panel VAR addresses the endogeneity problem because this methodology treats all the variables in the system as endogenous. Moreover, the panel VAR also helps us overcome a data limitation problem by stacking the data from various countries, allowing many short data series to be joined into one long data series. An added advantage of the panel VAR is that it allows us to take into account unobserved country specific heterogeneity. As such, the use of panel VARs seems appropriate for our analysis. Once we estimate the panel VAR, we derive variance decompositions (VCDs) and impulse response functions (IRFs). The VCDs allow us to determine how much of the forecast error variance of each variable can be attributed to shocks to itself and to other variables in the system. The IRFs provide additional insights by allowing us to trace, over time, how a particular variable responds to shocks to other variables in the system.

Before estimating the model, a stationarity test is conducted on the variables. The result of the Levin, Lin \& Chut test is shown in Table 5. It indicates that all the variables are stationary in level, except trade and saving variables. In addition to that, the cointegration between endogenous variables (Infant mortality, GDP per capita growth rate, Investment and ODA) has also been examined.

Table 2: Stationarity test

\begin{tabular}{|c|c|c|r|c|c|}
\hline & \multicolumn{5}{|c|}{ Levin, Lin \& Chut test } \\
\hline$\#$ & Variable & \multicolumn{2}{|c|}{ Level } & \multicolumn{2}{c|}{ First Difference } \\
\hline & & Statistic & $\begin{array}{l}\text { P- } \\
\text { value }\end{array}$ & Statistic & P-value \\
\hline 1 & FDI & $-4.30^{* *}$ & 0.00 & $-10.5720^{* * *}$ & 0.00 \\
\hline 2 & Investment & $-17.20^{* * *}$ & 0.00 & $-12.8911^{* * *}$ & 0.00 \\
\hline 3 & ODA & $-10.41^{* * *}$ & 0.00 & $-4.6619^{* * *}$ & 0.00 \\
\hline 4 & Infant Mortality & $-11.14^{* * *}$ & 0.00 & $-6.5867 * * *$ & 0.00 \\
\hline 5 & Trade & -1.05 & 0.14 & $-22.33^{* * *}$ & 0.00 \\
\hline 6 & Saving & -1.64 & 0.05 & $-20.63 * * *$ & 0.00 \\
\hline 7 & GDP per capita & $-17.01^{* * *}$ & 0.00 & $-20.2046^{* * *}$ & 0.00 \\
\hline 8 & Real interest rate & $-7.46^{* * *}$ & 0.00 & $-8.6591^{* * *}$ & 0.00 \\
\hline
\end{tabular}

Notes: *,** and *** indicates the significance at respectively $10 \%, 5 \%$ and $1 \%$ confidence level

The Impulse Response functions (IRF) are obtained by the Cholesky decomposition. In order to remove the fixed effect inherent to panel data, we use the forward mean-differencing, also known as Helmert procedure (Arellano and Bover, 1995). Since the fixed effects are correlated with the regressors due to lags of the dependent variables, the mean-differencing procedure commonly used to eliminate fixed effects would create biased coefficients. The Helmert transformation consists in subtracting each variable by its forward mean.

In order to have the IRF, the ordering of the endogenous variables need to be specified. According to the objective of this thesis, which is to assess the aid effectiveness, we first order ODA, next comes domestic investment, economic growth and infant mortality. The idea behind this ordering is that ODA is given to a country to fill the capital gap and enhance the investment capabilities, which will increase economic growth and in turn, will reduce poverty levels. After this step, a simultaneous system is estimated. In this case, we must assure that equations are identified. A structural equation is identified only when enough of the system's predetermined variables are omitted from the equation in question to allow this equation to be distinguished from all others in the system (Wooldridge (2010)). All the equations are proved to be identified; the procedure is described in annex. Therefore, they can be estimated by the twostage least squares (2SLS) and three-stage least squares (3SLS). However, according to Wooldridge 
(2010), system estimation methods (3SLS) are more efficient than estimating each equation by 2SLS; so, the results of the 3 SLS regressions are presented in this paper.

\subsection{Estimation results}

\section{Analysis of results}

The impulse response functions obtained by the VAR regression (see Appendix) show that after a shock in ODA, the level of investment increases, this effect is statistically significant after 3 years. Likewise, the response function of economic growth to a shock in ODA shows a positive reaction in the beginning years, but starts to decline just after two (2) years. However, this effect is not significant as regards to the confidence interval. Surprisingly, the relationship on Infant mortality is positive, meaning that after a shock in the amount of ODA per capita, the rate of infant mortality increases.

Table 3: Variance of Decomposition

\begin{tabular}{|c|l|l|l|l|}
\hline Variables & ODA & INVEST & GDP & INFANT \\
\hline 2 years ahead & & & & \\
\hline ODA & 98.70075 & 0.475448 & 0.366523 & 0.457275 \\
\hline INVEST & 1.596073 & 98.02817 & 0.001116 & 0.374642 \\
\hline GDP & 2.255812 & 2.476484 & 95.20337 & 0.064335 \\
\hline INFANT & 0.101306 & 0.082376 & 1.066743 & 98.74958 \\
\hline 5 years ahead & & & & \\
\hline ODA & 98.46853 & 0.686833 & 0.363494 & 0.481146 \\
\hline INVEST & 3.971780 & 94.94363 & 0.343020 & 0.741568 \\
\hline GDP & 2.357471 & 5.778320 & 87.74631 & 4.117901 \\
\hline INFANT & 0.182674 & 0.323527 & 1.956665 & 97.53713 \\
\hline 10 years ahead & & & & \\
\hline ODA & 95.57820 & 2.090143 & 1.391996 & 0.939659 \\
\hline INVEST & 8.625192 & 88.43258 & 1.696214 & 1.246009 \\
\hline GDP & 2.460824 & 8.301979 & 84.20439 & 5.032811 \\
\hline INFANT & 0.539785 & 0.500101 & 4.803126 & 94.15699 \\
\hline
\end{tabular}

Notes: Percent of variation in the row variable explained by column variable.

Looking at the variance decomposition, it is shown that, 2 years ahead, less than 2 percent of the variation of ODA are explained by the variations of others variables, namely domestic investment, GDP growth rate and infant mortality. ODA explains $1.6 \%$ of the domestic investment and $2.25 \%$ of GDP variations. The domestic investment explains $2.47 \%$ of GDP variation.

Five years later, $4 \%$ of domestic investment variations are explained by ODA and $5.77 \%$ of GDP variations are explained by domestic investment. Furthermore, a ten years' period analysis indicates that around $9 \%$ of investment variation are explained by ODA and $8.3 \%$ of GDP changes are predicted by variation in domestic investment.

It can then be concluded that as time continues forward, more variations are observed respectively on the GDP growth rate and the domestic investment. Variations of domestic investment are caused by ODA, while GDP variations are due to domestic investment.

The results of the simultaneous equations model are shown in Table 7. The first equation explains the infant mortality as a proxy of poverty level. The coefficient of the ODA variable appears to be significant and negative, suggesting that there is a negative relationship between the ODA and infant mortality. This implies that foreign aid contributes to a reduction of infant mortality. An increase of 100 US dollars in ODA per capita reduces infant mortality rate by 5 in 1000 births. The level of GDP per capita affects also significantly the poverty level; the sign of this variable is negative, showing that an increase by 1 percentage point in GDP growth rate reduces the number of children's death by around 7 in every 1000 births. The lagged value of ODA (ODA of the 4 previous years) is added to test the hypothesis that the current poverty level might be affected by previous amounts of ODA. That is to say, the effect of ODA can happen four years later. However, this variable after estimation is non-significant. 
Table 4: Estimation results

\begin{tabular}{|c|c|c|c|c|}
\hline & (1) & (2) & (3) & (4) \\
\hline VARIABLES & $\begin{array}{l}\text { Infant } \\
\text { mortality }\end{array}$ & GDP growth & Investment & ODA \\
\hline \multirow[t]{2}{*}{ Initial GDP growth } & $-0.0169 *$ & -0.00188 & & 0.584 \\
\hline & $(0.00970)$ & $(0.00131)$ & & $(2.697)$ \\
\hline \multirow[t]{2}{*}{ FDI } & & $-0.246 * * *$ & $0.321 * * *$ & \\
\hline & & $(0.0955)$ & $(0.0644)$ & \\
\hline Investment & & $\begin{array}{c}1.162 * * * \\
(0.261)\end{array}$ & & \\
\hline Human Capital & & $\begin{array}{c}6.680 * * * \\
(1.138)\end{array}$ & & \\
\hline \multirow[t]{2}{*}{ ODA } & $-0.0491 * * *$ & $-0.0257 * * *$ & $0.0227 * * *$ & \\
\hline & $(0.0150)$ & $(0.00705)$ & $(0.00344)$ & \\
\hline \multirow[t]{2}{*}{ Lagged ODA } & 0.0186 & $0.00746^{* * *}$ & -0.00398 & \\
\hline & $(0.0113)$ & $(0.00291)$ & $(0.00269)$ & \\
\hline Trade & & $\begin{array}{c}-0.00536^{* * *} * \\
(0.00196)\end{array}$ & & \\
\hline \multirow[t]{2}{*}{ Saving } & & -0.0122 & 0.00767 & \\
\hline & & (0.00892) & (0.00957) & \\
\hline \multirow[t]{2}{*}{ Governance } & 0.526 & -0.265 & 0.128 & $-51.01 * * *$ \\
\hline & $(2.334)$ & $(0.493)$ & $(0.458)$ & $(14.44)$ \\
\hline Pop growth & $\begin{array}{l}-1.120 \\
(2.413)\end{array}$ & & & \\
\hline \multirow[t]{2}{*}{ Initial infant Mortality } & $0.681 * * *$ & & & $-2.788 * * *$ \\
\hline & $(0.0733)$ & & & $(0.559)$ \\
\hline \multirow[t]{2}{*}{ GDP growth } & $-6.391 * * *$ & & & $-17.77 *$ \\
\hline & $(1.571)$ & & & $(9.172)$ \\
\hline Real interest rate & & & $\begin{array}{c}0.0381 \\
(0.0293)\end{array}$ & \\
\hline Observations & 137 & 137 & 137 & 137 \\
\hline
\end{tabular}

Standard errors in parentheses, $* * * \mathrm{p}<0.01, * * \mathrm{p}<0.05, * \mathrm{p}<0.1$

Notes: The governance indicator is the average of political right and civil liberties indicators from Freedom House database. POLITICAL RIGHTS assigns a value of 1 to countries with the most political rights and a value of 7 to countries with the least such rights. CIVIL LIBERTIIES assigns a value of 1 to countries with the most civil freedoms and a value of 7 to countries with the least such freedom.

The second equation explains the relationship between the growth rate of the GDP per capita and ODA. From the estimation, the current level of ODA is likely to decrease the growth rate of GDP per capita. However, there is a positive effect of lagged ODA on economic growth; meaning that the economic growth is affected by previous amounts of aid received. Also, domestic investment is revealed to affect economic growth positively and significantly. Moreover, the FDI and Trade variables are signed negatively.

The convergence hypothesis is also tested by controlling the initial levels of GDP per capita and infant mortality (Asra et al, 2015). Indeed, according to Solow (1957), one should expect a country's initial level of income to have an independent negative effect on its subsequent economic growth rate. That is to say, countries that start out poorer, other things equal might be expected to experience higher rates of economic growth, leading to convergence in levels of income across countries over time. According to the estimation results, there seems to be a convergence with regards to the GDP growth rate, meaning that in the context of West African countries, countries with less GDP growth rate in 1980 seem to catch up with those which started with a higher GDP growth rate in the beginning year; but this effect is not statistically significant. However, the sign of initial infant mortality reveals opposite patterns; countries with a high infant mortality rate in 1980 are still experiencing a higher number of children death compared to those with a less infant mortality rate in 1980.

We also assume in the model, that domestic investment is endogenous. Indeed, the results show that the level of foreign direct investment affects positively and significantly the level of domestic investment. Therefore, in the ECOWAS countries, foreign direct investment appears as a driving force for domestic investment. These countries should, attract more foreign investment in sectors that contributes more to the economic growth. The aid variable is signed positively and significantly, showing that ODA contributes to 
increasing the investment in recipient countries. Finally, equation 4 shows that the allocation of ODA is determined by the level of governance, the initial infant mortality as a proxy of poverty level and the GDP growth rate. These variables are significant and signed negatively, which means that as the economic situation improves in recipient countries, the donors provide less amount of aid. Regarding the governance, high level of the index is associated with less political rights and civil liberties. Thus, the negative sign of the indicator means that as the governance situation gets worse in a country, donors decrease their allocation.

\subsection{Discussion}

An examination of the direct effect of each variable on endogenous variables reveals that ODA appears to produce good results regarding poverty alleviation by decreasing infant mortality rate. Likewise, foreign aid seems to be a positive determinant of domestic investment in ECOWAS. This conclusion is similar to Adamu (2013) and Gomanee et al. (2005) who find that in the Sub-Saharan region, the effectiveness of aid is channeled by investment. Also, Foreign Direct Investment has a positive effect on the domestic investment in recipient countries. Furthermore, the negative sign of the GDP per capita in the poverty equation is expected as it means that the individual economic situation is an important determinant of the poverty level.

However, economic growth is likely to be hampered by the flow of foreign aid. This seems to support the view of authors such as Trumbull and Wall (1994) and Alesina and Dollar (2000) who claim that there is a negative effect of foreign aid on economic growth. Although this result is unexpected, it can be explained by the distribution of ODA in ECOWAS countries; indeed, a large proportion of aid is attributed to social sectors (health, education). These sectors do not have an impact on economic growth in the short term compared to the manufacture and agriculture sectors. Furthermore, during the 1980s, most of the countries in the sample experienced low economic growth due to external shocks related to the decline of the price of raw materials, and due to internal armed conflicts. Another reason mentioned by Moyo (2009) is related to the corruption and bad governance in recipient countries. The effect of institutions and governance has been assessed in this study; however, the coefficient of the governance variable is non-significant.

This finding of a negative effect of aid on economic growth is in line with Eregha et al. (2012). In their paper, Eregha et al. only analyze the ECOWAS countries and conclude that the result of a negative effect of aid is not surprising because most of these countries divert aid for unproductive consumption uses and such aid flow also facilitates corruption. The effect of domestic investment on economic growth is conform to the theory since it is revealed that it is a positive determinant (Mankiw et al. 1992; Sala-i-Martin et al. 2004).

Another result from this equation is the negative effect of FDI and Trade on GDP per capita growth rate. This can also be explained by the fact that most of the FDI in West African countries are directed into the primary sector. Moreover, as it has been shown by Alvaro (2003), FDI flows into the different sectors of the economy (namely; primary, manufacturing, and services) and exert different effects on economic growth. FDI inflows into the primary sector tend to have a negative effect on growth, whereas FDI inflows in the manufacturing sector have a positive effect; this effect is ambiguous when FDI is directed to the service sector. Eregha et al. (2012) also finds that a negative effect of trade might be as a result of high dependency on importation influenced by aid flow that might undermine growth. Furthermore, it might be attributed to the fact that the export base of these countries is primary product oriented and the demand for primary product is inelastic. So if aid has a negative influence on exchange rate, then this result is not surprising.

The ODA equation indicates that as the governance in recipient countries gets worse, donors decrease their financial support. This result highlights the fact that governance influences aid allocation towards West African Countries. This may be due to the suspicion of mismanagement and less effectiveness. However, the negative sign of GDP per capita means that when donors realized the good economic results of the recipient countries, they provide less financial assistance. Higher the GDP per capita, lower is the amount of aid allocated.

\subsection{Robustness check.}

In order to assure the robustness of the results, the poverty indicator is changed and replaced by the Human Development Indicator (HDI), also the governance indicator is replaced by an index from the six governance indicators of World Governance Indicators. This index was calculated by using the principal component approach. Although, the sample period changes from 2002 to 2014, the results (table 8) suggest a positive relationship between ODA and HDI, confirming the previous results. As the amount of ODA increases, the human development index increases, although the impact is very low. As well as in the previous estimation, the impact of ODA on economic growth is negative, but non-significant. 
Table 5: Estimations results using HDI as poverty indicator

\begin{tabular}{|c|c|c|c|c|}
\hline & (1) & $(2)$ & (3) & (4) \\
\hline VARIABLES & HDI & GDP growth & Investment & ODA \\
\hline \multirow[t]{2}{*}{ Initial GDP per capita } & $-0.00346 * * *$ & $1.044 *$ & & $-15.47 * * *$ \\
\hline & $(0.000713)$ & $(0.623)$ & & $(4.748)$ \\
\hline \multirow[t]{2}{*}{ FDI } & & 0.118 & $0.384 * * *$ & \\
\hline & & $(0.110)$ & $(0.106)$ & \\
\hline Investment & & $-0.445 * * *(0.157)$ & & \\
\hline Human capital & & $\begin{array}{l}24.90 * \\
(13.78)\end{array}$ & & \\
\hline \multirow[t]{2}{*}{ ODA } & $8.52 \mathrm{e}-05 * * *$ & -0.0137 & 0.0142 & \\
\hline & $(3.20 \mathrm{e}-05)$ & $(0.0170)$ & $(0.0226)$ & \\
\hline \multirow[t]{2}{*}{ Lagged ODA } & $0.000206^{* * *}$ & -0.0384 & $-0.116^{* * *}$ & \\
\hline & $(4.69 \mathrm{e}-05)$ & $(0.0393)$ & $(0.0403)$ & \\
\hline Trade & & $\begin{array}{c}0.0873 * * \\
(0.0371)\end{array}$ & & \\
\hline \multirow[t]{2}{*}{ Saving } & & -0.0307 & 0.0551 & \\
\hline & & $(0.0398)$ & $(0.0590)$ & \\
\hline \multirow[t]{2}{*}{ Governance } & $0.0192 * * *$ & $2.144 * * *$ & $3.566^{* * *}$ & 34.79 \\
\hline & $(0.00392)$ & $(0.572)$ & $(0.782)$ & $(29.30)$ \\
\hline Pop growth & $\begin{array}{c}-0.00208 \\
(0.00337) \\
\end{array}$ & & & \\
\hline \multirow[t]{2}{*}{ Initial infant mortality } & $-1.10 \mathrm{e}-05$ & & & $3.361^{*}$ \\
\hline & $(0.000280)$ & & & $(1.942)$ \\
\hline \multirow[t]{2}{*}{ GDP per capita } & -0.000658 & & & 0.647 \\
\hline & $(0.00117)$ & & & $(9.295)$ \\
\hline Real interest rate & & & $-0.414 * *(0.168)$ & \\
\hline \multirow[t]{2}{*}{ Constant } & $0.357 * * *$ & -30.63 & $27.02 * * *$ & -432.9 \\
\hline & $(0.0448)$ & $(20.51)$ & $(4.348)$ & $(285.8)$ \\
\hline Observations & 20 & 20 & 20 & 20 \\
\hline
\end{tabular}

Standard errors in parentheses

$* * * \mathrm{p}<0.01, * * \mathrm{p}<0.05, * \mathrm{p}<0.1$

\section{Conclusion And Policy Recommendations}

Aid effectiveness is one topic on which many researchers have focused their attention over the years. The major contribution of this study is that the effectiveness of aid has been assessed regarding its impact on poverty instead of economic growth, as well as the consideration for the specific region of West Africa. First, a panel VAR analysis was conducted in order to analyze the interactions between ODA, GDP per capita, Domestic investment and Infant mortality. The impulse response functions obtained by the Cholesky decomposition show that the domestic investment increases after an innovation in foreign aid and this effect is statistically significant. The effect on economic growth is also positive up to two (2) years, there after it decreases. However, the effect on infant mortality rate is ambiguous. Therefore, a simultaneous equations model was estimated and in support of previous studies (Morrissey et al, 2004), the results show that aid helps to reduce poverty by decreasing the infant mortality rate. The hypothesis tested was that foreign aid has a positive effect on capital accumulation and investment, which in turn increases economic growth and reduces poverty. After estimation, a positive effect of ODA on domestic investment was revealed, likewise the effect of investment on economic growth was found to be positive. Also, our results show a contributing effect of economic growth to poverty alleviation. However, analyzing the direct effect of ODA on the endogenous variables, we found that its effect on economic growth was harmful in line with the pessimistic view of aid effectiveness (Alesina and Dollar, 2000). Therefore, it can be concluded that the foreign aid is, in general, propoor but not growth enhancing in ECOWAS countries.

A policy recommendation from this study is that West African countries should seek more ODA in direction of growth enhancing sectors such as infrastructure and manufacture sectors. This could lead to a greater impact on poverty. Moreover, they should encourage the domestic investment which contributes more to economic growth than Foreign Direct Investment. Another aspect of this study concerns the analysis of governance effect in these countries. It has been shown that the improvement in governance contributes to the 
reduction the poverty level and increases the economic growth. Therefore, to achieve low poverty level, recipient countries should combine reforms to improve their institution management.

\section{References}

[1]. A. Alesina,., and D. Dollar Who Gives Foreign Aid to Whom and Why?. Journal of Economic Growth, 5(1)2000: 33-63.

[2]. Alesina, A., and B. Weder 2002 "Do Corrupted Governments Receive Less Foreign Aid?" American Economic Review, 92(4): $1,126-37$

[3]. Arellano and Bover "Another look at the instrumental variable estimation of error-components models" Journal of Econometrics, 68(1) 1995,29-51

[4]. Askarov "Development Aid and Growth in Transition Countries". World Development, 66, 2015, $383-399$.

[5]. A.Asra, , G. Estrada, , Y.Kim, , M.G..Quibria, Poverty and Foreign Aid.Evidence from Recent Cross-Country Data, ERD Working Paper N. 65.Manila: 2005, Asian Development Bank.

[6]. C.. Arndt, , S.Jones, , F.Tarp,. Aid, growth, and development: have we come full circle? Journal of Globalization and Development 1 (2), 2010, article 5

[7]. Bacha, E. L. "A Three-Gap Model of Foreign Transfer and the GDP Growth Rate in Developing Countries". Journal of Development Economics, 32(2): 1990, 279-96.

[8]. Barro, R.J. 1996. "Determinants of Economic Growth: A Cross-Country Empirical Study". National Bureau of Economic Research, Cambridge, Working Paper N. 5698.

[9]. Research Centre Working Paper 35.

[10]. Boone, P. 1994 'The Impact of Foreign Aid on Savings and Growth'. Centre for Economic Performance Working Paper 677. London: London School of Economics.

[11]. Boone, P. 1996 "Politics and the Effectiveness of Foreign Aid". European Economic Review, 40(2): $289-329$.

[12]. Bourguignon, F., Leipziger, D. 2006. Aid, growth, and poverty reduction: toward a new partnership model. Washington, DC: World Bank.

[13]. Burnside, C., and D. Dollar. 1997. “Aid, Policies and Growth”. World Bank Policy Research Working Paper 1777. Washington, DC: World Bank.

[14]. Burnside, C., and D. Dollar. 2000. “Aid, Policies and Growth”. American Economic Review, 90(4): 847-68.

[15]. Chenery, H., and M. Bruno. 1962. "Development Alternatives in an Open Economy: The Case of Israel". Economic Journal, 72(285): 79-103.

[16]. Chenery, H., and S. Strout. 1966. "Foreign Assistance and Economic Development”. American Economic Review, 66(1): 679-753.

[17]. Carl-Johan Dalgaard. 2004. "On the Empirics of Foreign Aid and Growth". The Economic Journal,

[18]. Collier, P. and D. Dollar. 2002. “Aid Allocation and Poverty Reduction”. European Economic Review, 46(8)

[19]. Dalgaard, C-J., H. Hansen, and F. Tarp. 2004. "On the Empirics of Foreign Aid and Growth". The Economic Journal, 114(496): F191- F216.

[20]. Easterly, W., and R. Levine. 2001. "It's Not Factor Accumulation: Stylized Facts and Growth Models". World Bank Economic Review, 15(2): 177-219.

[21]. Eregha et al. 2012. "Foreign aid flows, investment and economic growth in Africa: Does uncertainty matters?" African Journal of Social Sciences, Volume 2 (2), 100-107

[22]. Eskander Alvi, D. 2008. "Aid, Policies, and Growth in Developing Countries A New Look at the Empirics". Southern Economic Journal, Vol. 74, No. 3, 693-706

[23]. Friedman, M. 1958. "Foreign Economic Aid" Yale Review, 47(4): 501-16.

[24]. Gomanee, K., S. Girma and O. Morrissey. 2002, "Aid, Investment and Economic Growth in Sub-Saharan Africa". A paper Presented at the 10th General Conference of EADI, LjubIjana, 19-21 September

[25]. Gomanee, K., Girma, S., Morrissey, O. 2003. 'Searching for Aid Threshold Effects'. Centre for Research in Economic Development and International Trade, Nottingham, CREDIT Research Paper N. 03/15.

[26]. Gomanee, K., O. Morrissey, P. Mosley, and A. Verschoor 2005b. “Aid, Government, Expenditure, and Aggregate Welfare”. World Development, 33(3): 355-70

[27]. Greene, W. H. 2003. Econometric Analysis, 5th ed. Upper Saddle River: Prentice Hall

[28]. Guillaumont, P. and L. Chauvet. 2001. “Aid and performance: A reassessment”. The Journal of Development Studies, 37(6): 66-92

[29]. Guillaumont P. 2009. "EVI and its Use. Design of an Economic Vulnerability Index and its Use for International Development Policy". UNU-WIDER Research Paper 2008/99 Forthcoming in Oxford Development Studies.

[30]. Hadjimichael, M. T., D. Ghura, M. Muhleisen, R. Nord, and E.M. Ucer. 1995. "Sub-Saharan African Growth, Savings and Investment", 1986-93'. IMF Occasional Papers, 118 Washington, DC: International Monetary Fund.

[31]. Hansen, H. and F. Tarp. 2000, "Aid effectiveness disputed," Journal of International Development, 12, $375-398$.

[32]. Hansen, H. and F. Tarp. 2001, "Aid and growth regressions," Journal of Development Economics, vol.64, p.547-570.

[33]. Wooldridge, J. M. 2010. Econometric Analysis of Cross Section and Panel Data. Cambridge, MA: MIT Press

Appendix

1.Variables description

\begin{tabular}{|l|l|l|l|}
\hline Variable & Definition & Source \\
\hline Endogenous & & \multicolumn{3}{|l|}{} \\
\hline $\begin{array}{l}\text { Human } \\
\text { Index }\end{array}$ & Devel & $\begin{array}{l}\text { The Human Development Index } \\
\text { is a composite statistic of life }\end{array}$ & UNDP \\
\hline
\end{tabular}




\begin{tabular}{|c|c|c|}
\hline & $\begin{array}{l}\text { expectancy, education, and } \\
\text { income per capita indicators. }\end{array}$ & \\
\hline Infant Mortality & $\begin{array}{l}\text { Infant mortality rate is the number } \\
\text { of infants dying before reaching } \\
\text { one year of age, per } 1,000 \text { live } \\
\text { births in a given year. }\end{array}$ & $\begin{array}{l}\text { World } \\
\text { indicator (2015) }\end{array}$ \\
\hline Aid per capita & $\begin{array}{l}\text { Flows to countries and territories } \\
\text { on the DAC list of ODA } \\
\text { Recipients and to multilateral } \\
\text { institutions }\end{array}$ & $\begin{array}{l}\text { World } \\
\text { indicator (2015) }\end{array}$ \\
\hline $\begin{array}{l}\text { Real GDP per } \\
\text { growth rate }\end{array}$ & $\begin{array}{l}\text { Real Growth rate of Gross } \\
\text { Domestic Product }\end{array}$ & $\begin{array}{l}\text { World } \\
\text { indicator (2015) }\end{array}$ \\
\hline $\begin{array}{l}\text { Gross Domestic } \\
\text { investment as a } \\
\text { percentage of GDP }\end{array}$ & $\begin{array}{l}\text { Gross Fixed Capital Formation as } \\
\text { proxy of domestic investment }\end{array}$ & $\begin{array}{l}\text { World } \\
\text { indicator (2015) }\end{array}$ \\
\hline \multicolumn{3}{|l|}{ Exogenous } \\
\hline Initial conditions & $\begin{array}{l}\text { Level of infant mortality, GDP per } \\
\text { capita growth rate }\end{array}$ & $\begin{array}{l}\text { World } \\
\text { indicator (2015) }\end{array}$ \\
\hline $\begin{array}{l}\text { Trade as a percentage of } \\
\text { GDP }\end{array}$ & $\begin{array}{l}\text { Trade is the sum of exports and } \\
\text { imports of goods and services } \\
\text { measured as a share of gross } \\
\text { domestic product. }\end{array}$ & $\begin{array}{l}\text { World } \\
\text { indicator (2015) }\end{array}$ \\
\hline Real interest rate & $\begin{array}{l}\text { Real interest rate is the lending } \\
\text { interest rate adjusted for inflation } \\
\text { as measured by the GDP deflator }\end{array}$ & $\begin{array}{l}\text { World } \\
\text { indicator (2015) }\end{array}$ \\
\hline Population growth rate & $\begin{array}{l}\text { Population growth rate is the } \\
\text { exponential rate of growth of } \\
\text { midyear population from year t-1 } \\
\text { to t, expressed as a percentage. }\end{array}$ & $\begin{array}{l}\text { World } \\
\text { indicator (2015) }\end{array}$ \\
\hline Governance indicators & $\begin{array}{l}\text { Civil liberties and political right } \\
\text { indicator are used as political } \\
\text { determinants / An index } \\
\text { computed by the Principal } \\
\text { component approach from the six } \\
\text { world Governance Indicators. }\end{array}$ & $\begin{array}{l}\text { Freedom House/ } \\
\text { governance indicator } \\
(2015)\end{array}$ \\
\hline Human capital index & $\begin{array}{l}\text { Index of human capital per } \\
\text { person, based on years of } \\
\text { schooling (Barro and Lee 2013) } \\
\text { and returns to education } \\
\text { (Psacharopoulos 1994). }\end{array}$ & $\begin{array}{l}\text { Penn Word Table (version } \\
8.1 \text { ) }\end{array}$ \\
\hline $\begin{array}{l}\text { Real Saving } \\
\text { a } \\
\text { percentage of GDP }\end{array}$ & Gross savings & WDI (2015) \\
\hline
\end{tabular}

2.Impulse response functions

Response to Cholesky One S.D. Innovations \pm 2 S.E.

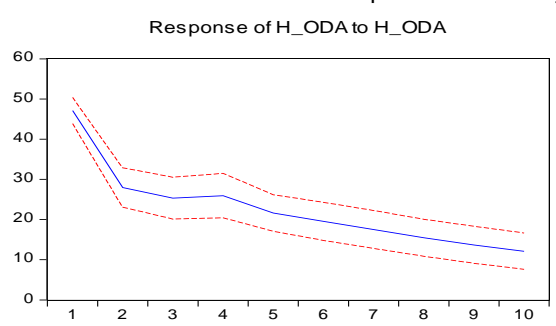

Response of H_INV to H_ODA
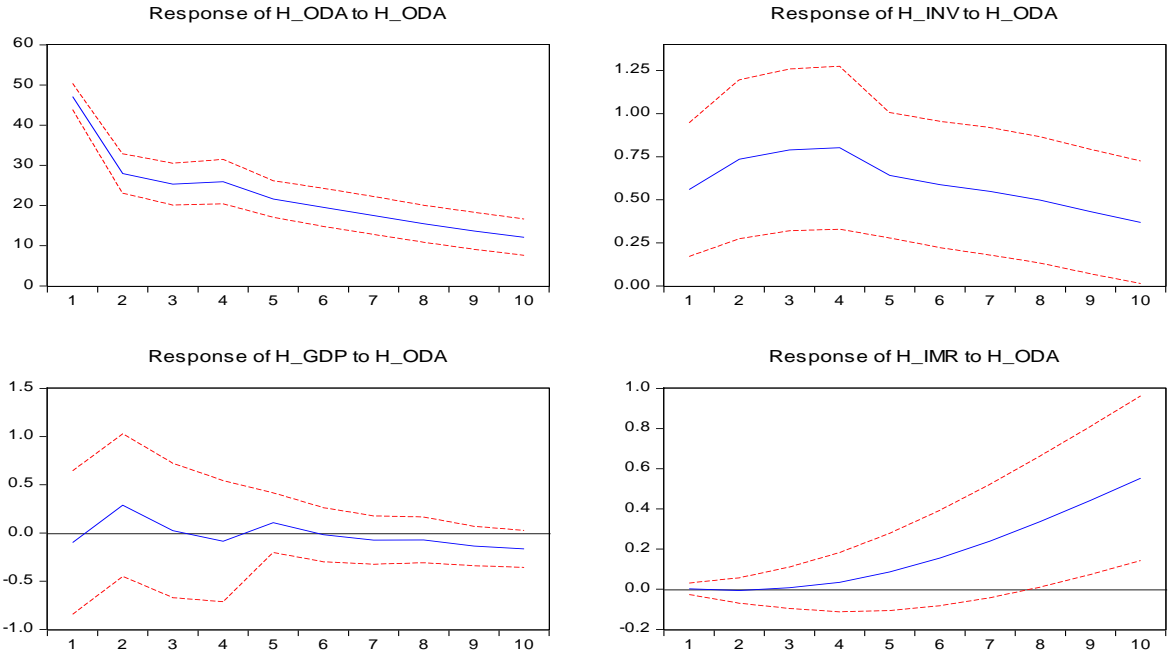